\title{
MEDIA TAHU KUNING UNTUK MENINGKATKAN AKTIVITAS DAN PRESTASI BELAJAR MATEMATIKA
}

\author{
Yudi Hamdan Dardiri ${ }^{1}$, Ebih Ar Arhasy ${ }^{2}$ \\ ${ }^{1}$ SMPN 2 Talaga, ${ }^{2}$ Universitas Siliwangi \\ 188102025@student.unsil.ac.id ${ }^{1}$, arhasy55@gmail.com²
}

\begin{abstract}
Student activities and achievements on the material opportunities are still weak, discussions with classical completeness daily test material opportunities obtained by students who have completed $69.23 \%$. The purpose of selecting this paper is to describe the improvement of mathematics learning activities and achievement of students who use Yellow Tofu Media. The method used in this research is classroom action research (CAR using 2 cycles, each cycle for 4 x 40 minutes). The results showed student achievement increased to $81.81 \%$ in the first cycle, and increased again to $86.36 \%$ in the second cycle. Based on the observation sheet, students' mathematics learning activeness increased from the first meeting $32 \%$ in the first cycle to the second meeting in the second cycle by $83 \%$. The conclusion of this paper is learning by using yellow tofu media can increase students' learning activities and achievement. Based on the conclusion above, the author agrees and replicates the media that can be used as a medium for learning mathematics. The next researcher can develop a replica of tofu media in Research and Development (R\&D) research so that the replica of tofu media is feasible and valid to be used as a learning medium.
\end{abstract}

Keywords: Learning media, Activities, Yellow Tofu Media

\begin{abstract}
Abstrak
Aktivitas dan prestasi siswa pada materi peluang masih lemah, ditunjukkan dengan ketuntasan klasikal ulangan harian materi peluang yang mencapai siswa yang telah tuntas sebesar $69,23 \%$. Tujuan penelitian paper ini adalah untuk mendeskripsikan peningkatan aktivitas dan prestasi belajar matematika siswa dengan menggunakan Media Tahu Kuning. Metode yang digunakan dalam penelitian ini adalah penelitian tindakan kelas (PTK dengan menggunakan 2 siklus, yang masing masing siklus selama 4 x 40 menit). Hasil penelitian menunjukkan prestasi siswa meningkat menjadi $81,81 \%$ pada siklus I, dan meningkat lagi menjadi 86,36 \% pada siklus II. Berdasarkan dari lembar observasi, keaktifan belajar matematika siswa mengalami peningkatan dari pertemuan pertama $32 \%$ pada siklus I sampai pertemuan kedua siklus II sebesar $83 \%$. Simpulan dari paper ini adalah pembelajaran dengan menggunakan media tahu kuning dapat meningkatkan aktivitas dan prestasi belajar peserta didik. berdasarkan kesimpulan di atas, peneliti menyarankan memodifikasi dan mereplika media tahu sehingga dapat digunakan sebagai media pembelajaran matematika. Untuk peneliti selanjutnya dapat mengembangkan replika media tahu dalam penelitian Reseach And Depelovment (R\&D) sehingga replika media tahu layak dan valid digunakan sebagai media pembelajaran.
\end{abstract}

Kata kunci: Media pembelajaran, Aktivitas, Media Tahu Kuning

Received: June 17, 2020 / Accepted: July 17, 2020 / Published Online: August 26, 2020 
Jurnal Lebesgue : Jurnal Ilmiah Pendidikan Matematika, Matematika dan Statistika

Yudi Hamdan Dardiri, Ebih Ar Arhasy

Volume 1, No. 2, Agustus 2020 hal.91-104

DOI Artikel : 10.46306/lb.v1i2.20

\section{Pendahuluan}

Kondisi ideal pembelajaran bisa terbentuk jika dalam proses pembelajaran khususnya pembelajaran matematika sebagai mother of science, guru mampu membimbing peserta didik terlatih dan terkondisi untuk belajar mandiri. Kreativitas dan kemandirian siswa menjadi sasaran dan kebutuhan yang harus dikembangkan dalam pembelajaran matematika di Indonesia (Susilawati, 2009). Guru sebagai salah satu faktor keberhasilan pembelajaran, mampu menciptakan suasana pembelajaran yang menyenangkan (Rosyana, 2014). Guru mampu merubah paradigama matematika yang selama ini melekat di peserta didik bahwa matematika sebagai mata pelajaran yang membosankan dan membingunkan. Guru juga mengajar dengan menggunakan metode yang sangat variatif dan tidak monoton. Variatif disini maksudnya adalah guru mampu menghubungkan materi dengan masalah sehari-hari atau masalah nyata dan menggunakan media nyata dalam membantu memahami konsep matematika dan menyelesaikan masalah matematika.

Selain itu seluruh peserta didik harus terlibat aktif dalam proses pembelajaran tidak hanya duduk mendengarkan penjelasan guru (Utami, 2009). Sehingga terasa oleh peserta didik akan kebermaknaan matematika dalam kehidupan sehari-hari/dunia nyata. Selama ini pembelajaran dan pengajaran Matematika di Indonesia selalu berpusat pada guru, mekanistik, dan dipraktikkan secara konvensional dengan tujuan utama dari pengajaran ini hanyalah menghafal fakta, konsep dan formula (Arsaythamby \& Zubainur, 2014). Siswa diperintahkan untuk menghafal banyak fakta dan mereka harus dapat memuntahkannya selama ujian (Zubainur, Darmiati, Ibrahim \& Su'id, 2009; Ahmad, 2002). Menurut Johnson (dalam Djafar, 2011) menghubungkan suatu pelajaran dengan kehidupan nyata membuat hasilnya menjadi bermakna. Ini akan membuat siswa merasa bahwa belajar itu penting buat masa depannya.

Ramadani \& Novrita (2019) menyebutkan bahwa salah satu penyebab yang membuat siswa tidak konsentrasi dan tidak fokus dalam pembelajaran, sehingga hasil belajar makin terus menurun adalah pemilihan media pembelajaran yang monoton. Hasil wawancara yang dilakukan peneliti kepada beberapa guru matematika bahwa kebanyakan guru selalu menggunakan media power point dalam pembelajaran. Sejalan dengan Karina (2019) mengatakan media pembelajaran yang selama ini dipilih guru seperti power point, yang hanya berisi informasi itu termasuk media monoton, media yang membosankan. Media seperti itu menyebabkan siswa menjadi kurang aktif pada proses pembelajaran yang mempengaruhi kurangnya hasil belajar siswa. Apalagi kalau tidak menggunakan media pembelajaran sama sekali atau kurang menggunakan media pemebelajaran.

Masykur, Nofrizal dan Syazali (2017) kurangnya penggunaan media mengasumsi terhadap penyebabnya proses pembelajaran yang monoton dan kurang kreatif. Dalam proses pembelajaran matematika setelah mengabsen guru langsung menjelaskan rumus matematika memberikan contoh soal dilanjutkan dengan memberikan soal latihan tanpa menggunakan media yang membantu peserta 
Jurnal Lebesgue : Jurnal Ilmiah Pendidikan Matematika, Matematika dan Statistika

Yudi Hamdan Dardiri, Ebih Ar Arhasy

Volume 1, No. 2, Agustus 2020 hal.91-104

DOI Artikel : 10.46306/lb.v1i2.20

menemukan konsep dan dan melibat-aktifkan peserta didik dalam menemukan konsep matematika dengan bantuan media tersebut.

Matematika merupakan salah satu mata pelajaran yang diajarkan pada setiap jenjang pendidikan formal (Supriyanti, 2020) oleh karena itu Peneliti berusaha untuk mencari strategi pembelajaran yang tepat dan efisien untuk meningkatkan aktivitas dan prestasi belajar matematika peserta didik serta sarana penunjang yang memungkinkan sebagai bentuk kearifan lokal di Kecamatan Talaga Kabupaten Majalengka, banyak industri rumah yang memproduksi Tahu, Makanan Tahu bisa digunakan sebagai media pada mata pelajaran Matematika konsep peluang, belum ada yang melakukan penelitian penggunaan media tahu kuning dalam pembelajaran, khususnya pembelajaran matematika maka peneliti ingin menggunakan Tahu sebagai medianya. Peneliti juga bisa mendapatkan jawaban yang berarti tentang penggunaan Tahu dapat menambahkan ketertarikan peserta didik terhadap matematika dan bahwa benda nyata yang berada di lingkungan kita dan benda-benda yang sepele bisa menjadi media pembelajaran.Selain itu dikarenakan materi ini adalah materi yang monoton, contoh digunakan hanya berupa uang logam dan dadu, tetapi tingkat pemahaman peserta didik terhadap konsep peluang selalu dibawah harapan perlu ide kreatif untuk menggali media yang dapat digunakan di materi peluang dan inovasi pembelajaran yang dapat digunakan adalah penggunaan media tahu dalam proses pembelajaran matematika materi peluang.

Momentum mengimplementasikan kurikulum 2013 menurut Anggraeni (2016), ada beberapa karakteristik yang dapat dicapai oleh guru seperti mengembangkan keseimbangan antara sikap spiritual dan sosial, pengetahuan dan keterampilan, serta menerapkan berbagai situasi di sekolah dan di masyarakat, memberikan pengalaman belajar agar peserta didik mampu menerapkan apa yang dipelajari di sekolah ke masyarakat dan memanfaatkan masyarakat sebagai sumber belajar dengan cara menempatkan sekolah sebagai bagian dari masyarakat yang. Media tahu kuning termasuk media konkret yaitu benda yang dapat dilihat dan dialami oleh siswa sehingga memberikan pengalaman kepada mereka (Ashar, 2012: 54). Media tahu kuning sangat inovatif sebagai media yang membantu meningkatkan aktivitas belajar peserta didik sehingga terbentuk kemandirian sebagai salah satu cara mengintegrasikan penguatan pendidikan karakter. Penggunaan media tahu kuning dalam proses belajar matematika akan membantu mengejawantahkan nilai-nilai pendidikan karakter ranah psikomotorik (keterampilan) dari output belajar peserta didik. Media tahu sesungguhnya merupakan objek yang dapat menstimulus siswa dalam mempelajari pengetahuan tertentu terutama menyangkut keterampilan (psikomotorik) tertentu (Djamarah \& Zain, 2006: 121).

Media tahu Kuning yang digunakan peneliti sebagai inovasi pembelajaran terinspirasi dari pengkajian literatur penelitian yang dilakukan oleh Astuti \& Indianto (2014). Akan tetapi, terdapat beberapa perbedaan antara penelitian Astuti \& Indianto dengan penelitian ini. Pertama, media konkret yang digunakan dalam penelitian Astuti \& Indianto adalah media konkret untuk mempelajari materi perkalian dan tidak disebutkan secara spesifik benda apa saja yang digunakan, sedangkan dalam 
Jurnal Lebesgue : Jurnal Ilmiah Pendidikan Matematika, Matematika dan Statistika

Yudi Hamdan Dardiri, Ebih Ar Arhasy

Volume 1, No. 2, Agustus 2020 hal.91-104

DOI Artikel : 10.46306/lb.v1i2.20

penelitian ini media yang digunakan dalam pembelajaran menggunakan media Tahu Kuning untuk materi peluang. Kedua, dalam penelitian Astuti \& Indianto dilakukan pada siswa tunagrahita ringan di kelas VI semester 1 VI SLB C Setya Darma, sedangkan penelitian ini dilakukan di kelas IX-A semester 2 SMP Negeri 2 Talaga Kabupaten Majalengka.

Penelitian yang lain oleh Deviana \& Prihatnani (2018), perbedaannya dengan penelitian ini adalah satu, dalam penelitiaan Deviana \& Prihatnani untuk mempelajari materi peluang dipelajari menggunakan media monopoli sedangkan penelitian ini dalam mempelajari materi peluang dipelajari dengan menggunakan media tahu kuning. Ketdua, penelitian Deviana \& Prihatnani telah diterapkan pada siswa kelas IX-I SMP Negeri 1 Salatiga, sedangkan penelitian ini dilakukan di kelas IX-A semester 2 SMP Negeri 2 Talaga Kabupaten Majalengka. Alasan pemilihan kelas tersebut karena berdasarkan hasil pengamatan peneliti, di kelas tersebut masih banyak siswa yang tidak antusias dalam mengikuti proses belajar matematika.

Dari dua penelitian yang relevan di atas dan dari hasil pengkajian beberapa literatur, media tahu kuning sebagai media pembelajaran belum pernah diterapkan dalam penelitian lain dan belum pernah digunakan dalam pembelajaran oleh siapapun dan dimanapun, sehingga muncul judul "Media Tahu Kuning Untuk Meningkatkan Aktivitas dan Prestasi Belajar Matematika”.

\section{METODE PENELITIAN}

Penelitian ini adalah penelitian yang bertujuan memperbaiki kondisi pembelajaran siswa kelas IX-A SMP Negeri 2 Talaga pada materi peluang menggunakan media tahu kuning kuning, sehingga jenis penelitian yang dipilih adalah penelitian tindakan kelas (PTK dengan menggunakan 2 siklus. Yang masing masing siklus selama 4 x 40 menit). Dalam pelaksanaan penelitian ini diawali dengan hasil analisa keterlaksanaan kurikulum di kelas IX-A, dimana kompetensi prasyarat dengan materi Peluang ini sudah dimiliki.

Sebelum mengadakan tindakan pada penelitian ini, maka peneliti mengadakan tes untuk mencari data kompetensi awal penguasaan materi Peluang dari siswa, serta tanya jawab kepada siswa dan guru yang mengajar kelas tersebut untuk mengetahui tentang pembelajaran sebelumnya tentang materi prasarat, dan observasi aktivitas siswa saat belajar dengan lembar observasi yang sudah disiapkan untuk mengetahui keaktifan siswa saat belajar.

Kondisi awal kelas yang di dapat dari sebelum penelitian ini digunakan sebagai langkah untuk membuat desain perangkat pembelajaran pada siklus penelitian. Seperti telah dijelaskan sebelumnya bahwasannya pada penelitian tindakan kelas ini dilakukan dalam 2 siklus namun bila dari siklus yang direncanakan masih terdapat masalah yang harus dipecahkan maka dapat dilanjutkan dengan siklus berikutnya. Adapun setiap siklus memiliki tahapan-tahapan (1) Tahap perencanaan tindakan (mempersiapkan kebutuhan pelaksanaan tindakan), (2) Tahap pelaksanaan tindakan (meliputi pendahuluan, kegiatan inti, dan penutup), (3) Tahap observasi tindakan (Observasi dilakukan bersamaan 
Jurnal Lebesgue : Jurnal Ilmiah Pendidikan Matematika, Matematika dan Statistika

Yudi Hamdan Dardiri, Ebih Ar Arhasy

Volume 1, No. 2, Agustus 2020 hal.91-104

DOI Artikel : 10.46306/lb.v1i2.20

pada saat guru sedang melaksanakan proses pengajaran dan siswa melakukan aktivitas belajarnya), (4) Tahap refleksi (Refleksi dilakukan untuk menilai keterlaksanaan tindakan pembelajaran, sehingga hasilnya merupakan temuan-temuan yang dapat diinterpretasikan guru dan observer untuk menyusun rencana tindakan ke siklus berikutnya).

Selain itu dalam pelaksanaannya peneliti melibatkan guru sejenis sebagai kolaborator membantu dan mengevaluasi jalannya observasi ini serta memberikan sumbang saran demi perbaikannya. Instrumen yang digunakan dalam penelitian ini berupa (1) lembar observasi yang mencakup aspek Memberikan ide kepada kelompoknya, Menanyakan kepada kelompoknya jika ada permasalahan yang tidak dimengerti, Memberikan pertanyaan yang sesuai dengan hasil presentasi diskusi kelompok lain, Mendengarkan ide dari kelompoknya, Memberikan tanggapan terhadap pertanyaan dari kelompok lain, Menarik kesimpulan hasil diskusi, dan Menanggapi pertanyaan guru. (2) Lembar test yang berupa posttest untuk mengukur kompetensi siswa dalam bidang pengetahuan, dan keterampilan.

Pada penelitian tindakan kelas ini proses validasi data dilakukan dengan meminta penilaian terhadap para guru mata pelajaran sejenis berkenaan dengan isi dan kisi - kisi dari tes tertulis serta blanko pengamatan aktivitas siswa yang digunakan sebagai alat pengumpul data, sehingga alat yang digunakan untuk mengukur kemampuan siswa dalam penelitian ini kevalidannya dapat dipertanggung jawabkan.

Metode pengumpulan data data yang digunakan dalam penenlitian ini, 1) Metode Observasi, yaitu pengamatan yang dilakukan terhadap aktivitas siswa dan guru dalam kegiatan mempelajari materi peluang menggunakan media tahu kuning melalui lembar pengamatan aktivitas siswa dan guru yang diisi oleh teman sejawat. 2) Metode Tes. Tes yang digunakan pada penelitian ini adalah tes berbentuk soal essay sebanyak 5 soal dengan skor maksimal 100, tes yang diberikan kepada siswa dilaksanakan pada akhir pelajaran. Selanjutnya dilakukan analisis data. Analisis data dalam penelitian ini menggunakan metode: 1) Data hasil observasi, data yang diperoleh dari lembar observasi kemudian dihitung prosentasenya. Untuk menghitung nilai aktifitas belajar siswa menggunakan rumus sebagai berikut:

Keakfitan siswa $=\frac{\text { Skor yang diperoleh }}{\text { Skor maksimal }} \times 100$

Nilai yang didapat kemudian dinyatakan dalam bentuk rentangan. Pencapaian nilai klasikal dihitung menggunakan rumus sebagai berikut:

\section{$\sum$ siswa yang berpredik at aktif dan sangat aktif $\mathrm{x} 100 \%$ \\ $\sum$ seluruh siswa}

2) Data hasil tes, data hasil tes formatif dianalisis secara deskriptif kuantitatif-kualitatif. Untuk data hasil prestasi siswa ditentukan dengan menggunakan rumus: $\mathrm{N}$ Prestasi siswa $=\sum \mathrm{N}$ siswa tiap soal. Setelah diperoleh nilai prestasi belajar kemudian dihitung ketuntasan belajar secara klasikal jika $80 \%$ siswa dari jumlah siswa secara keseluruhan dinyatakan tuntas belajar. Ketuntasan secara klasikal dihitung dengan menggunakan rumus: 
Jurnal Lebesgue : Jurnal Ilmiah Pendidikan Matematika, Matematika dan Statistika

Yudi Hamdan Dardiri, Ebih Ar Arhasy

Volume 1, No. 2, Agustus 2020 hal.91-104

DOI Artikel : 10.46306/lb.v1i2.20

\section{N. Klasikal $=\sum$ Siswa yang tuntas belajar $\times 100 \%$ $\sum$ Siswa}

Untuk KKM pelajaran Matematika kelas IX disebut tuntas belajar apabila telah mencapai KKM 75. Hasil penelitian tindakan kelas ini tercapai sesuai dengan harapan bila dalam penelitian ini (1) Penguasaan materi materi peluang siswa, pada akhir penelitian ini meningkat hingga mencapai nilai diatas batas KKM, dan (2) Penerapan penggunaan media Tahu Kuning efektif digunakan untuk menyampaikan materi Peluang dalam hal ini ditandai dengan peningkatan hasil nilai yang didapatkan masing - masing siswa, dan (3) Terjadi peningkatan aktivitas siswa saat belajar kompetensi Peluang dalam setiap aspek, meliputi memberikan ide kepada kelompoknya, menanyakan kepada kelompoknya jika ada permasalahan yang tidak dimengerti, memberikan pertanyaan yang sesuai dengan hasil presentasi diskusi kelompok lain, mendengarkan ide dari kelompoknya, memberikan tanggapan terhadap pertanyaan dari kelompok lain, menarik kesimpulan hasil diskusi, menanggapi pertanyaan guru.

\section{Hasil dan PembahasaN}

Hasil Penelitian Siklus I

Perencanaan Tindakan

Tahap perencanaan pada siklus I dimulai dengan berkoordinasi teman sejawat selaku kolaborator. Koordinasi dilakukan untuk membahas perencanaan pelaksanaan tindakan atau skenario pembelajaran dan berbagai persiapan pembelajaran agar terjadi kesepahaman apa dan bagaimana proses pembelajaran menggunakan media tahu kuning, materi pelajaran, dan menyiapkan instrumen penelitian seperti Silabus, RPP, LKS, lembar observasi dan angket.

Pelaksanaan Tindakan

Kegiatan Awal

Peneliti memberi salam, mengecek kehadiran siswa dan meyakinkan bahwa siswa siap untuk belajar. Peneliti menyampaikan materi, tujuan, dan manfaat kompetensi yangdipelajari, serta model pembelajaran PBL yang dilakukan selama proses pembelajaran. Peneliti memberikan sedikit motivasi kepada siswa tentang penggunaan materi peluang dan manfaatnya dalam menyelesaikan masalah yang ada dalam kehidupan sehari-hari

Kegiatan Inti

Siswa memperhatikan stimulus yang diberikan guru berupa kasus yang berkaitan dengan materi Peluang. Peneliti memberikan stimulus selama 30 menit. Setelah memberikan penjelasan materi, selanjutnya siswa berdiskusi untuk mengerjakan soal diskusi tersebut dengan anggota kelompoknya. Kemudian hasil diskusi yang telah dikerjakan setiap kelompok dipresentasikan di depan kelas. Setiap kelompok diberikan kesempatan bertanya kepada kelompok yang sedang mempresentasikan hasil 
Jurnal Lebesgue : Jurnal Ilmiah Pendidikan Matematika, Matematika dan Statistika

Yudi Hamdan Dardiri, Ebih Ar Arhasy

Volume 1, No. 2, Agustus 2020 hal.91-104

DOI Artikel : 10.46306/lb.v1i2.20

diskusinya di depan kelas, kelompok lain diperbolehkan memberikan pendapat atau saran terkait tentang materi yang disampaikan.

Hasil Pengamatan Aktivitas

Hasil pengamatan siswa melakukan aktivitas selama siklus I dapat dilihat pada tabel 1 di bawah ini.

Tabel 1 Hasil Aktivitas Selama Siklus I

\begin{tabular}{|c|c|c|c|c|}
\hline \multirow[t]{2}{*}{ No. } & \multirow[t]{2}{*}{ Aktivitas yang Diamati } & \multicolumn{2}{|c|}{$\begin{array}{l}\text { Jumlah Siswa } \\
\text { yang Aktif }\end{array}$} & \multirow{2}{*}{$\begin{array}{l}\text { Rata- } \\
\text { Rata } \\
\text { Aktivitas } \\
(\%)\end{array}$} \\
\hline & & 1 & 2 & \\
\hline 1. & Memberikan ide kepada kelompoknya & 8 & 13 & 47,73 \\
\hline 2. & $\begin{array}{l}\text { Menanyakan kepada kelompoknya jika ada permasalahan } \\
\text { yang tidak dimengerti }\end{array}$ & 6 & 10 & 36,36 \\
\hline 3. & $\begin{array}{l}\text { Memberikan pertanyaan yang sesuai dengan hasil presentasi } \\
\text { diskusi kelompok lain }\end{array}$ & 6 & 12 & 40,91 \\
\hline 4. & Mendengarkan ide dari kelompoknya & 10 & 16 & 59,09 \\
\hline 5. & $\begin{array}{l}\text { Memberikan tanggapan terhadap pertanyaan dari kelompok } \\
\text { lain }\end{array}$ & 7 & 9 & 36,36 \\
\hline 6. & Menarik kesimpulan hasil diskusi & 3 & 5 & 18,18 \\
\hline 7. & Menanggapi pertanyaan guru & 9 & 14 & 52,27 \\
\hline
\end{tabular}

Data Observasi

Dari hasil pengamatan observer pada siklus I bahwa siswa kurang aktif bertanya saat temannya mempresentasikan kerja kelompoknya ke depan, mungkin karena mereka masih malu-malu dan belum terbiasa berbicara didepan kelas serta soal yang diberikan kepada masing-masing kelompok sama dan mereka sudah membahas soal tersebut dalam kelompok. Sehingga saat kelompok lain tampil kedepan mengerjakan soal tersebut mereka kurang tertarik, sehingga tidak aktif bertanya karena jawaban mereka dengan jawaban di depan sama.

Dari tabel 1 di atas diketahui bahwa persentasi hasil observasi pengelolaan pembelajaran menggunakan media tahu kuning

Persentase hasil observasi $=\frac{\text { Jumlah skor }}{\text { Jumlah maksimal } \text { skor }} \times 100 \%$

$$
=\frac{41}{55} \times 100 \%=74,55 \%
$$

Hasil ini menunjukkan bahwa masih perlu diperbaiki untuk pengelolaan pembelajaran menggunakan media tahu kuning oleh peneliti pada siklus II agar hasil yang dicapai lebih maksimal. Hasil penilaian kompetensi

Setelah pelaksanaan siklus I selesai dan diadakannya Tes Siklus I (Pertemuan terakhir siklus I), ternyata prestasi belajar materi peluang menggunakan media tahu kuning pada siswa Kelas IX A SMP Negeri 2 
Jurnal Lebesgue : Jurnal Ilmiah Pendidikan Matematika, Matematika dan Statistika

Yudi Hamdan Dardiri, Ebih Ar Arhasy

Volume 1, No. 2, Agustus 2020 hal.91-104

DOI Artikel : 10.46306/lb.v1i2.20

Talaga semester gasal dapat ditunjukkan pada Tabel 2.

Tabel 2 Hasil Belajar Siklus I

\begin{tabular}{lllll}
\hline No & Rentang Nilai & Jumlah & Persentase & Keterangan \\
\hline $\mathbf{1}$ & $<70$ & 4 & $18,18 \%$ & Belum Tuntas \\
\hline $\mathbf{2}$ & $70-89$ & 12 & $54,54 \%$ & Tuntas \\
\hline $\mathbf{3}$ & $\geq 90$ & 6 & $27,27 \%$ & Tuntas \\
\hline & Jumlah & 22 & $100 \%$ & Ketuntasan klasikal 81,81\%
\end{tabular}

Dari tabel 2 menunjukan Daya serap klasikal yang merupakan hasil belajar seluruh siswa mencapai sebesar $81,81 \%$, berarti sudah lebih besar dari yang ditetapkan sebesar $80 \%$ dan dapat dikatakan tuntas secara klasikal, tetapi belum sesuai dengan harapan peneliti. Oleh karena itu dari hasil belajar pada siklus I ini, bahwa proses pembelajaran yang menggunakan media tahu kuning perlu ditingkatkan lagi pada siklus berikutnya yaitu siklus II.

\section{Refleksi}

Adapun refleksi yang perlu dilakukan pada siklus II agar hasilnya sesuai harapan adalah: 1) menekankan kepada siswa tentang pentingnya kerjasama ketika melakukan tugas kelompok, 2) lebih melibatkan diri untuk membantu siswa mencapai hasil yang maksimal agar siswa sukses dalam belajar, 3) meyakinkan siswa bahwa mereka mampu untuk mengerjakan tugas kelompok maupun individu, 4) membuat suasana belajar lebih kondusif yang membuat lingkungan belajar berubah menjadi lingkungan yang menyenangkan sehingga siswa merasa nyaman dalam proses pembelajaran, 5) guru/peneliti diharapkan mampu untuk menumbuhkan rasa mampu dan senang belajar siswa, membiasakan siswa berpikir bahwa membuat kesalahan dalam belajar itu merupakan hal yang wajar sehingga siswa tidak merasa enggan untuk meningkatkan dan melatih kemampuannya dalam belajar agar dapat meningkatkan hasil belajarnya, 7) guru/peneliti perlu memberikan penghargaan kepada individu dan kelompok terbaik dalam mengerjakan tes yang diberikan guru/peneliti agar dapat memotivasi minat siswa untuk mendapatkan nilai terbaik, sehingga siswa menjadi bersemangat dalam mengikuti proses pembelajaran. Hasil Penelitian Siklus II

Perencanaan

Pada perencanaan siklus II ini peneliti merencanakan tindakan dengan mempertimbangkan hasil refleksi pada siklus sebelumnya sebagai berikut: (1) Membuat kelompok yang terdiri dari 4-5 orang masing - masing kelompok digambarkan denah tempat diskusinya dengan tujuan agar guru kolaborator lebih mudah dalam mengamati aktifitas siswa, (2) Membuat rancangan pembelajaran materi peluang 2 x 40 menit, (3) Membuat 4 lembar kerja yang dipergunakan untuk diskusi kelompok, (4) Membuat soal tes siklus II untuk mengukur kemampuan siswa setelah mengikuti kegiatan di siklus ke dua, (5) Menganalisa hasil test siklus II untuk menjadi bahan pembelajaran berikutnya.

Pelaksanaan Tindakan 
Jurnal Lebesgue : Jurnal Ilmiah Pendidikan Matematika, Matematika dan Statistika

Yudi Hamdan Dardiri, Ebih Ar Arhasy

Volume 1, No. 2, Agustus 2020 hal.91-104

DOI Artikel : 10.46306/lb.v1i2.20

Setelah pembukaan dan pendahuluan dilanjutkan dengan penjelasan kepada siswa tentang penggunaan media tahu kuning untuk menentukan peluang suatu kejadian. Siswa berkumpul dengan kelompoknya dan mengerti prosedur kerjanya maka peneliti membagikan lembar kerja siswa untuk didiskusikan bersama dari masing-masing kelompok. Pada saat siswa mulai berdiskusi peneliti berkeliling untuk membimbing serta memberikan umpan agar siswa bisa menyelesaikan lembar kerjanya.

Disaat bersamaan guru kolaborator mencatat aktifitas siswa siswa dengan berbantuan denah tempat duduk siswa dalam kelompok, dan mengamati perilakunya sesuai poin yang sudah direncanakan, dilanjutkan dengan meminta perwakilan kelompok untuk mempresentasikan secara singkat hasil kerjanya dan kelompok lain diminta menanggapi apa yang telah dipresentasikan, pada kesempatan ini peneliti memandu jalannya diskusi dan menuntun untuk mendapatkan kesimpulan.

Hasil Pengamatan Aktifitas

Hasil pengamatan observer tentang jumlah siswa yang melakukan aktifitas pada siklus II dapat dilihat pada tabel 3 berikut :

Tabel 3 Hasil Aktivitas Selama Siklus II

No. Aktivitas yang Diamati

Jumlah Siswa

Rata-Rata

12

Aktifitas (\%)

1. Memberikan ide kepada kelompoknya $\quad 13 \quad 18$

2. Menanyakan kepada kelompoknya jika ada permasalahan $12 \quad 19$ yang tidak dimengerti

70,46

3. Memberikan pertanyaan yang sesuai dengan hasil presentasi $15 \quad 17$ diskusi kelompok lain

4. Mendengarkan ide dari kelompoknya $17 \quad 18$

5. Memberikan tanggapan terhadap pertanyaan dari kelompok $15 \quad 19$ lain

6. Menarik kesimpulan hasil diskusi

$14 \quad 17$

7. Menanggapi pertanyaan guru

1520

79,55

Dari tabel 3 di atas dapat dilihat jumlah siswa yang memberikan ide kepada kelompoknya, memberikan tanggapan terhadap pertanyaan dari kelompok lain dan menanggapi pertanyaan guru paling banyak yaitu hampir semua siswa sudah terlibat aktif dalam semua kegiatan.

Data observasi

Data observasi yang diperoleh pada saat proses pembelajaran menggunakan media tahu kuning diperkuat dengan hasil data observasi yang dilakukan observer selama pembelajaran Persentasi hasil pengamatan pengelolaan pembelajaran dengan model PBL pada Siklus II menggunakan 
Jurnal Lebesgue : Jurnal Ilmiah Pendidikan Matematika, Matematika dan Statistika

Yudi Hamdan Dardiri, Ebih Ar Arhasy

Volume 1, No. 2, Agustus 2020 hal.91-104

DOI Artikel : 10.46306/lb.v1i2.20

rumus :

Persentase hasil observasi $=\frac{\text { Jumlahskor }}{\text { Jumlahmaksimalskor }} \times 100 \%$

$$
=\frac{46}{55} \times 100 \%=83,63 \%
$$

Kondisi pada siklus II, seluruh rencana pembelajaran dengan model PBL siklus II sudah terlaksana dengan baik. Penyampaian materi lebih berkembang sebab sudah terbangun komunikasi dua arah yang tertib, guru menunjuk salah satu siswa untuk menjawab setiap pertanyaan dan tidak dijawab secara klasikal.

Hasil penilaian kompetensi

Setelah pelaksanaan siklus II selesai dan diadakannya tes secara tertulis, ternyata hasil belajar materi peluang suatu kejadian dengan menerapkan model PBL pada siswa kelas IX A SMP Negeri 2 Talaga semester gasal sebagaimana ditunjukkan pada tabel 4 .

Tabel 4 Hasil Belajar Siklus II

\begin{tabular}{lllll}
\hline No & Rentang Nilai & Jumlah & Prosentase & Keterangan \\
\hline $\mathbf{1}$ & $<70$ & 3 & $13,64 \%$ & Belum Tuntas \\
\hline $\mathbf{2}$ & $70-89$ & 11 & $50 \%$ & Tuntas \\
\hline $\mathbf{3}$ & $\geq 90$ & 8 & $36,36 \%$ & Tuntas \\
\hline Jumlah & 22 & $100 \%$ & Ketuntasan klasikal 86,36\%
\end{tabular}

Dari tabel 4 menunjukan hasil belajar pada siklus II, bahwa daya serap perorangan yang merupakan hasil belajar siswa melalui ulangan harian, dimana seseorang dikatakan tuntas belajar apabila telah memperoleh nilai sekurang-kurangnya 70 atau telah mencapai skor $70 \%$, ternyata siswa yang telah tuntas sebesar 86,36\% sedangkan siswa yang belum tuntas sebesar 13,64 \%. Daya serap klasikal yang merupakan hasil belajar seluruh siswa mencapai sebesar 86,36 \% yang berarti diatas Kriteria Ketuntasan Minimal (KKM ) yang ditetapkan sebesar $85 \%$.

\section{Refleksi}

Dari hasil evaluasi yang diberikan tenyata 19 siswa telah mampu mendapatkan nilai di atas batas ketuntasan minimal namun masih terlihat kesalahan yang dibuat oleh siswa dikarenakan faktor kekurang telitian siswa dalam bekerja dan masih berkaitan dengan materi sebelumnya. Masalah skill dan kecermatan dalam mengambil langkah pengerjaan masih perlu ditingkatkan agar penguaasaan materi peluang dapat lebih baik lagi. Keaktifan dari siswa secara keseluruhan telah sesuai yang diharapkan oleh peneliti karena dalam mengerjakan lembar kerja secara kelompok telah aktif dalam pembahasan lembar kerja yang diberikan. Penciptaan suasana saling berlomba dan bersaing menjadi yang terbaik ,juga perlu dikembangkan di setiap kelompok belajar.

Pembahasan

Media Tahu Kuning memberikan pengaruh yang signifikan terhadap peserta didik dan guru khususnya pada materi peluang. Terbukti dengan banyak manfaat yang diperoleh setelah menggunakan media tahu 
Jurnal Lebesgue : Jurnal Ilmiah Pendidikan Matematika, Matematika dan Statistika

Yudi Hamdan Dardiri, Ebih Ar Arhasy

Volume 1, No. 2, Agustus 2020 hal.91-104

DOI Artikel : 10.46306/lb.v1i2.20

kuning dalam proses pembelajaran pada materi peluang, diantaranya: (1) Pembelajaran materi peluang menjadi bersifat nyata karena menggunakan media yang sering mereka temukan di lingkungan seharihari mereka, (2) Menumbuhkembangkan penguatan pendidikan karakter yang terintegrasi dalam proses belajar pada saat berkelompok, seperti, mandiri, sikap toleransi, tidak memaksakan pendapat pribadi, mau mendengarkan teman pada saat mereka menjelaskan dll, (3) Karena kelompok yang dibentuk bersifat heterogen, didik yang pasif jadi termotivasi untuk mau bertanya kepada peserta didik lain yang telah lebih dahulu memahami materi dan petunjuk yang terdapat dalam lembar kerja siswa, (4) Pembelajaran menggunakan media tahu kuning menjadikan peserta didik lebih senang dalam belajar matematika materi peluang karena mereka yang menemukan konsep peluang dan memahami konsep peluang, (5) siswa akan lebih lama mengingat materi pelajaran materi peluang karena pembelajaran yang berkesan dan penuh makna. Pemahaman materi berasal dari pemanfaatan benda-benda yang ada di lingkungannya sebagai media dalam memahami materi matematika konsep peluang, (6) Pemahaman akan materi peluang yang diperoleh siswa berasal dari diri sendiri dan komprehensif dengan merujuk dan menyeleraskan dengan sumber-sumber belajar lainnya, (7) Menumbuhkan kedekatan positif yang lebih antara guru dengan peserta didik karena sering berkomunikasi ketika menemukan permasalahan saat melakukan kegiatan belajar dengan menggunakan tahu, dan (8) Meningkatkan aktivitas peserta didik dalam memahami, menemukan dan mengkomunikasikam materi matematika.

Berikut gambar aktivitas peserta didik dalam pembelajaran matematika materi peluang menggunakan media Tahu Kuning:
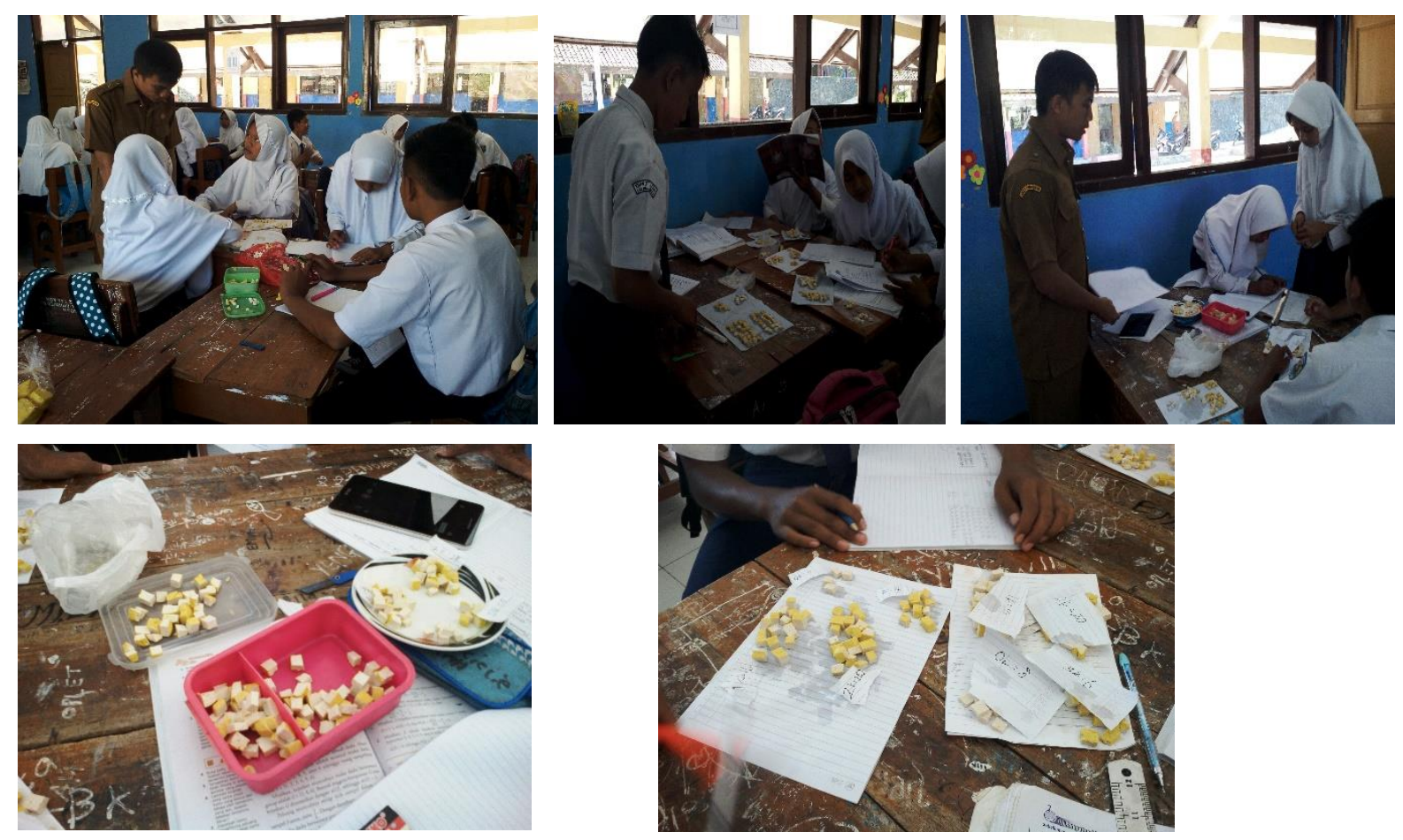

Gambar 1. Aktivitas pembelajaran menggunakan media tahu kuning

Berdasarkan hasil pelaksanaan tindakan mulai pemantauan keadaan awal hingga pelaksanaan tindakan 
Jurnal Lebesgue : Jurnal Ilmiah Pendidikan Matematika, Matematika dan Statistika

Yudi Hamdan Dardiri, Ebih Ar Arhasy

Volume 1, No. 2, Agustus 2020 hal.91-104

DOI Artikel : 10.46306/lb.v1i2.20

pada siklus II maka dapat digambarkan seperti di bawah ini:

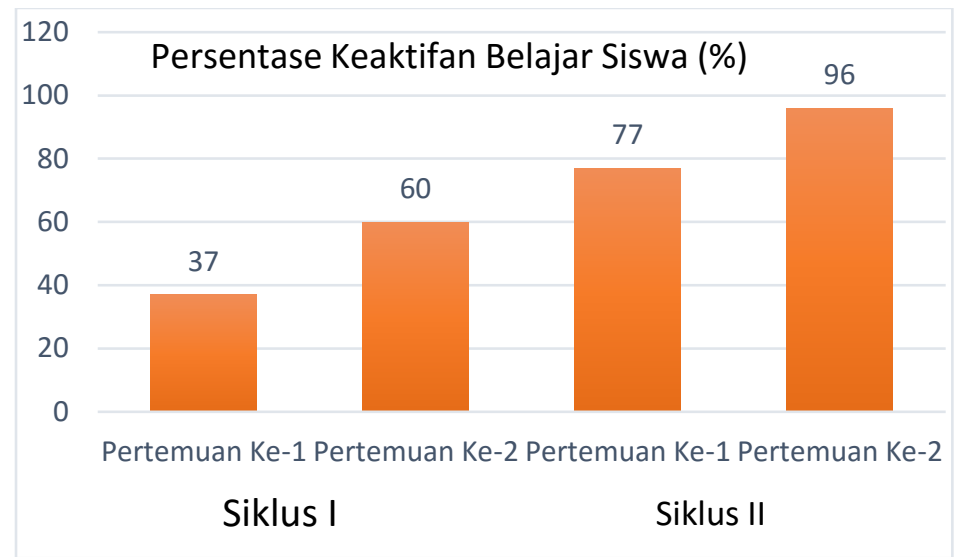

Gambar 2. Aktivitas siswa dalam setiap siklus

Perkembangan prestasi belajar dalam setiap siklus dapat digambarkan sebagai berikut:



Gambar 3. Perkembangan prestasi peserta didik

Pencapaian prosentasi keaktifan dan prestasi belajar peserta didik dalam setiap siklus dapat dilihat pada tabel sebagai berikut:

Tabel 5 Deskripsi Antar Siklus

\begin{tabular}{|c|c|c|c|c|}
\hline \multirow{2}{*}{ No } & \multirow{2}{*}{ Indikator } & \multicolumn{3}{|c|}{ Prosentasi yang dicapai } \\
\hline & & Awal & Siklus I & Siklus II \\
\hline 1 & $\begin{array}{l}\text { KEAKTIFAN } \\
\text { siswa dalam } \\
\text { belajar }\end{array}$ & - & $\begin{array}{c}\text { Keaktifan siswa } \\
\text { pertemuan ke-1 } \\
\text { sebesar } 37 \% \text { naik } \\
\text { menjadi } 60 \% \text { di } \\
\text { pertemuan ke-2 }\end{array}$ & $\begin{array}{l}\text { Keaktifan siswa } \\
\text { pertemuan ke-1 } \\
\text { sebesar } 77 \% \text { naik } \\
\text { menjadi } 96 \% \text { di } \\
\text { pertemuan ke-2 }\end{array}$ \\
\hline 2 & $\begin{array}{l}\text { Nilai Prestasi } \\
\text { belajar }\end{array}$ & $\begin{array}{c}\text { Tuntas } 69,23 \% \\
\text { Dengan rata rata } \\
\text { nilai } 70,81 \text {, nilai } \\
\text { minimal } 35 \text { dan } \\
\text { nilai maksimal } 95\end{array}$ & $\begin{array}{c}\text { Tuntas } 81,81 \% \\
\text { Dengan rata rata } \\
\text { nilai } 80,68, \text { nilai } \\
\text { minimal } 45 \text { dan nilai } \\
\text { maksimal } 100\end{array}$ & $\begin{array}{c}\text { Tuntas } 86,36 \% \\
\text { Dengan rata rata nilai } \\
86,59 \text {, nilai minimal } \\
60 \text { dan nilai } \\
\text { maksimal } 100\end{array}$ \\
\hline
\end{tabular}

Dari tabel deskripsi antar siklus tampak adanya hasil dari masing-masing indikator untuk mengukur aktivitas siswa setelah diberi tindakan mengalami peningkatan yang berarti, namun jika dilihat dari 
Jurnal Lebesgue : Jurnal Ilmiah Pendidikan Matematika, Matematika dan Statistika

Yudi Hamdan Dardiri, Ebih Ar Arhasy

Volume 1, No. 2, Agustus 2020 hal.91-104

DOI Artikel : 10.46306/lb.v1i2.20

target prosentase maka. Peningkatan hasil : (1) Keaktifan siswa masih perlu dicarikan solusi lain sehingga aktivitas siswa betul-betul fokus pada prestasi belajar yang dipelajari sehingga diharapkan semua siswa mempunyai aktivitas sangat tinggi terhadap pembelajarannya. Menurut Ayukmartina, Sujadi \& Purnami (2014) dan Rusminati \& Sulistyawati (2018) bahwa aktivitas matematika siswa dapat ditingkatkan dengan menggunakan model pembelajaran Think Pair Share (TPS). Keaktifan siswa juga dapat ditingkatkan dengan menggunakan metode Mind Map (Saputri \& Sungkono, 2019). (2) Walaupun prosentase aktivitas dalam setiap siklus meningkat, namun masih perlu terus dimotivasi dan didorong sehingga semua siswa bisa lebih bisa berpartisipasi aktif dalam pelaksanaan pembelajaran. Motivasi belajar siswa SMP dapat ditingkatkan dengan menerapkan model Group Investigation berbantuan Colour Ball (Riana, Kartinawati \& Suhito, 2019). Dari grafik perkembangan prestasi belajar siklus diatas tampak adanya hasil dari masing-masing indikator untuk mengukur prestasi belajar siswa setelah diberi tindakan mengalami peningkatan yang berarti, Penggunaan media Tahu kuning dalam pembelajaran Peluang dapat meningkatkan prestasi belajar siswa.

\section{KESIMPULAN}

Dari hasil data aplikasi praktis media tahu dalam pembelajaran matematika dan analisis data hasil aplikasi penggunaan media tahu dalam pembelajaran matematika materi peluang peneliti dapat menyimpulkan bahwa penggunaan media tahu kuning dapat meningkatkan aktifitas dan hasil belajar matematika kompetensi mengenal lambang bilangan pada siswa kelas 1 semester ganjil di SDN02 Kartoharjo Kecamatan Kartoharjo Kota Madiun Tahun Pelajaran 2017/2018. Hal ini dibuktikan dengan hasil yang dicapai dari prasiklus keaktifan siswa mencapai $22 \%$, pada siklusI keaktifan siswa mencapai $66,66 \%$, pada siklus II keaktifan siswa mencapai 100\%. Sedangkan data hasil ketuntasan belajar siswa pada pra siklus sebesar 22\%, ketuntasan belajar pada siklus I sebesar 44,44\%, ketuntasan pada siklus II sebesar $100 \%$. Untuk peneliti selanjutnya dapat mengembangkan replika media tahu kuning dalam penelitian Reseach And Depelovment (R\&D) sehingga replika media tahu kuning layak dan valid digunakan sebagai media pembelajaran.

\section{DAFTAR PUSTAKA}

Ahmad F. 2002 .Applying Realistic Mathematics Education in Teaching Geometry in Indonesian Primary School (Unpublished doctoral dissertation). University of Twente, Enschede.

Arsaythamby, V., \& Zubainur, C. M. 2014. How a Realistic Mathematics Educational Approach Affect Students' Activities in Primary Schools? Procedia - Social and Behavioral Sciences, 159, 309-313. doi:10.1016/j.sbspro.2014.12.378

Arsyad, A. 2009. Media Guru. Jakarta: PT Grafindo Persada.

Ashyar, A. 2012. Kreatif Mengembangkan Media Pembelajaran. Jakarta: Referensi 
Jurnal Lebesgue : Jurnal Ilmiah Pendidikan Matematika, Matematika dan Statistika

Yudi Hamdan Dardiri, Ebih Ar Arhasy

Volume 1, No. 2, Agustus 2020 hal.91-104

DOI Artikel : 10.46306/lb.v1i2.20

Astuti, W. dan Indianto. 2014. Penggunaan Media Benda Konkret untuk Meningkatkan Prestasi Belajar Matematika Tunagrahita pada Pokok Bahasan Perkalian. Jurnal Rehabilitasi dan Remediasi (JRR): Vol. 23, No. 1. hlm 22-28.

Ayukmartina, dkk. 2014. Upaya Meningkatkan Keaktifan Matematika Melalui Model Pembelajaran Think Pair Share Siswa Kelas VII D SMP N 1 Srumbung Kabupaten UNION: Jurnal Pendidikan Matematika: Vol. 2, No. 1, hlm 97-102.

Budimansyah, dkk. 2010. PAKEM Pembelajaran Aktif, Kreatif, Efektif dan Menyenangkan. Bandung: PT Genesindo.

Deviana, D. R. dan Prihatnani, E. 2018. Pengembangan Media Monopoli Matematika pada Materi Peluang untuk Siswa SMP: Jurnal Review Pembelajaran Matematika: Vol. 3, No. 2, hlm 114131.

Karina, dkk. 2019. Pengembangan Media Pemebelajaran Ular Tangga Kima (Ultrakim) Berbasis Kemaritiman pada Materi Hakikat Ilmu Kimia. Jurnal Zarah: Vol. 7, No. 1, hlm 13-16.

Masykur, dkk. 2017. Pengembangan Media Pembelajaran Matematika dengan Macromedia Flash AlJabar: Jurnal Pendidikan Matematika: Vol. 8, No. 2, hlm 177-186.

Ramadani, P. dan Novrita, S. R. 2019. Upaya Peningkatan Keaktifan dan Hasil Belajar Matematika Menggunakan Metode Mind Map pada Siswa Kelas VII SMP Negeri 2 Trucuk ABSIS: Mathematics Education Journal: Vol. 01, No. 01, hlm 32-35.

Riana, dkk. 2019. Meningkatkan Kemampuan Pemahaman Konsep dan Motivasi Belajar Siswa SMP Negeri 11 Semarang Melalui Model Group Investigation Berbantuan Colour Ball PRISMA 2: Prosiding Seminar Nasional Matematika.

Rosyana, W., Mulyani, S., \& Saputro, S. (2014). Pembelajaran Model TGT (Teams Games Tournament) Menggunakan Media Permainan Monopoli dan Permainan Ular Tangga pada Materi Pokok Sistem Koloid Ditinjau dari Kemampuan Memori Kelas XI SMA Negeri Sragen Tahun Pelajaran 2012/2013. Jurnal Pendidikan Kimia: Vol. 3, No. 4, hlm 74-81

Rusminati, S. H., \& Sulistyawati, I. 2018. Implementasi lesson study menggunakan model think pair share dan pendekatan saintifik. Premiere Educandum: Jurnal Pendidikan Dasar dan Pembelajaran, 8(1), 88-97.

Saputri, L. K. dan Sungkono, J. 2019. Peningkatan Hasil Belajar Keterampilan Menjahit Rok Melalui Media Mock Up di Kelas Tata Busana Siswa SLB Negeri 2 Padang. Gorga Jurnal Seni Rupa: Vol. 08, No. 01, hlm 203-209.

Supriyanti, A. (2020). PREDIKSI JUMLAH CALON PESERTA DIDIK BARU MENGGUNAKAN

METODE DOUBLE EXPONENTIAL SMOOTHING DARI BROWN ( Study Kasus : SD Islam

Al-Musyarrofah Jakarta ). Jurnal Lebesgue : Jurnal Ilmiah Pendidikan Matematika, Matematika

Dan Statistika, 1(1), 56-62. https://doi.org/10.46306/lb.v1i1

Susilawati, W. 2009. Belajar dan Pembelajaran Matematika Edisi II, Bandung: FTK UIN Sunan Gunung Djati Bandung.

Utami, R. P. 2009. Active Learning untuk Mewujudkan Pembelajaran Efektif, Al-Bidayah Jurnal Pendidikan: Vol. 1 No. 2, hlm 151-166.

Zubainur C., M., Darmiati, Ibrahim, Su'id (2009, Oktober). Kurikulum integratif dengan pendekatan realistik pada pembelajaran tematik di sekolah dasar. Majalah PMRI, 7(4), 54-58. 